\title{
Korelasi Karakter Pertumbuhan dan Hasil Kacang Panjang Lokal di Lahan Bekas Sawah
}

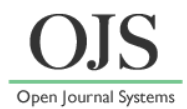

\author{
Eny Rolenti Togatorop*, Dia Novita Sari, Dian Novita, Edi Susilo, Parwito \\ Program Studi Agroteknologi, Fakultas Pertanian, Universitas Ratu Samban \\ *Email: eny28torop@gmail.com
}

DOI: https://doi.org/10.33369/pendipa.5.3.389-393

\begin{abstract}
High production of long beans is closely related to the variety used and growing environmental conditions. The selection process to obtain varieties with high yields is caused by the correlation between yield characters and yield components. The purpose of this research was to obtain information about the correlation between the growth and yield characters of long beans through correlation analysis. The research was conducted from July to September at the former rice fields of Muara Bangkahulu district and using local long bean genotypes. The experiment design used was completely randomized block design with three replications. Correlation analysis was performed on the character of leaf length, leaf width, harvesting age, pod length, pod diameter, weight per pod, number of pods per plant and pod weight per plant. The results showed that the leaf width character had a significant positive correlation with the pod diameter character. The characters of pod length, weight per pod and number of pods per plant had a significant positive correlation with the yield characters of pod weight per plant. The characters of pod length, weight per pod and number of pods per plant long bean genotypes can be used as parameters for the criteria selection.
\end{abstract}

Keywords: Genetic; genotype; characters; correlation; pod.

\begin{abstract}
ABSTRAK
Produksi kacang panjang yang tinggi sangat erat kaitannya dengan varietas yang digunakan maupun kondisi lingkungan tumbuh. Proses seleksi untuk mendapatkan varietas dengan daya hasil tinggi dipengaruhi oleh korelasi antar karakter hasil dan komponen hasil. Tujuan dari penelitian ini adalah untuk mendapatkan informasi tentang korelasi antar karakter pertumbuhan dan hasil kacang panjang melalui analisis korelasi. Penelitian telah dilaksanakan bulan Juli sampai dengan September 2020 di areal bekas persawahan Kelurahan Medan Baru dan bahan tanam yang digunakan dalam penelitian adalah genotipe kacang panjang lokal. Rancangan yang digunakan dalam penelitian yaitu Rancangan Kelompok lengkap teracak (RKLT) dengan tiga kali pengulangan. Analisis korelasi dilakukan terhadap data karakter panjang daun, lebar daun, umur panen, panjang polong, diameter polong, berat per polong, jumlah polong per tanaman dan berat polong per tanaman. Hasil penelitian menunjukkan bahwa karakter lebar daun berkorelasi positif nyata pada karakter diameter polong. Karakter panjang polong, berat per polong dan jumlah polong per tanaman berkorelasi positif nyata terhadap karakter hasil berat polong per tanaman. Karakter panjang polong, berat per polong dan jumlah polong per tanaman dapat digunakan sebagai pedoman untuk kriteria seleksi genotipe kacang panjang.
\end{abstract}

Kata kunci: Genetik; genotipe; karakter; korelasi; polong.

\section{PENDAHULUAN}

Kacang panjang (Vigna sinensis) merupakan tanaman yang tergolong ke dalam tanaman sayuran semusim. Kacang panjang termasuk sayuran yang bermanfaat bagi kesehatan tubuh karena mengandung serat, nutrisi, vitamin, asam amino, kalium dan sumber protein nabati (Narendri et al., 2017; Reswari et 
$a l, 2019)$. Pembudidayaan kacang panjang biasa dilakukan di dataran tinggi hingga menengah dan sangat sesuai menggunakan lahan yang gembur dan subur (BPPP, 2011), namun sebagian besar petani masih sering memanfaatkan lahan bekas sawah untuk menanam kacang panjang. Menurut Lantoi et al. (2016) tanah sawah merupakan tanah tergenang dengan kualitas tanah yang tergolong rendah unsur hara, bahan organik dan mikroba. Selain memanfaatkan lahan bekas sawah petani juga menggunakan genotipe lokal. Genotipe lokal yang ditanam biasanya menunjukkan keragaman tinggi baik dari segi keragaan maupun hasil. Menurut Fatimah et al. (2020) galur tanaman lokal yang memiliki tingkat keragaman yang tinggi dapat diperbaiki melalui seleksi galur yang berpotensi untuk pengembangan tetua persilangan. Kacang panjang menghendaki lingkungan dengan kondisi tanah kapasitas lapang (Hendriyani dan Setiari, 2007). Produksi kacang panjang yang tinggi sangat erat kaitannya dengan varietas yang digunakan maupun kondisi lingkungan tumbuh. Varietas yang bermutu baik belum tentu akan menghasilkan kacang panjang yang baik apabila tidak bisa beradaptasi di lingkungan luas. Untuk itu diperlukan upaya untuk merakit varietas kacang panjang yang dapat beradaptasi di lingkungan dengan kondisi jenuh air melalui program pemuliaan tanaman.

Pemuliaan tanaman merupakan kegiatan perakitan atau pengembangan suatu bahan genetik untuk menghasilkan varietas unggul baru. Pemuliaan tanaman dapat dilakukan dengan cara menyilangkan dua tetua genotipe yang memiliki sifat unggul beda (Sa'diyah et al., 2013). Pemanfaatan potensi genetik dan kaitannya dengan interaksi lingkungan untuk mendapatkan karakter tanaman baru sesuai dengan harapan pemulia merupakan tujuan dari pemuliaan tanaman (Subaedah et al., 2018). Menurut Lelang (2017), seleksi karakter produksi menjadi salah satu cara dalam pengujian varietas unggul, karena antara karakter pertumbuhan dan karakter komponen produksi dipengaruhi oleh keeratan genetik. Hal yang sama juga dilaporkan Elba et al. (2015) dan Gangapur et al. (2009) bahwa proses seleksi untuk mendapatkan varietas dengan produksi tinggi dipengaruhi oleh korelasi antar karakter hasil dan komponen hasil tanaman. Untuk mengetahui keterpautan antara karakter pertumbuhan dan hasil tanaman kacang panjang maka perlu dilakukan analisis korelasi. Tujuan dari penelitian ini adalah untuk mendapatkan informasi tentang korelasi antar karakter pertumbuhan dan hasil kacang panjang.

\section{METODE PENELITIAN \\ Waktu dan Lokasi Penelitian}

Pelaksanaan penelitian dilakukan di areal bekas persawahan Kelurahan Medan Baru, Bengkulu pada bulan Juli sampai dengan September 2020. Bahan tanam yang digunakan pada penelitian yaitu genotipe kacang panjang lokal yang berasal dari Bengkulu Selatan

\section{Rancangan Penelitian}

Rancangan yang digunakan dalam penelitian yaitu Rancangan Kelompok lengkap teracak (RKLT) dengan tiga kali pengulangan. Lahan penelitian untuk setiap ulangan berukuran $8 \mathrm{~m}$ x $3 \mathrm{~m}$, menggunakan jarak tanam $30 \mathrm{~cm}$ x 40 $\mathrm{cm}$. Penanaman dilakukan setelah 2 minggu pengolahan lahan dengan cara memasukkan 2 biji kacang panjang ke lubang tanam. Aplikasi pupuk dilakukan pada saat tanam menggunakan pupuk urea, SP36 dan $\mathrm{KCl}$ dengan dosis $200 \mathrm{~kg}$ per hektar. Pemeliharaan tanaman meliputi penyemprotan gulma, pembumbunan dan pemasangan ajir bambu. Pemupukan susulan dilakukan 3 kali setelah tanam dengan dosis yang sama pada saat pemupukan awal.

Pengamatan dilakukan terhadap karakter pertumbuhan dan hasil yang bterdiri dari panjang daun, lebar daun, umur panen, panjang polong, diameter polong, berat per polong, jumlah polong per tanaman dan berat polong per tanaman. Data yang dikumpulkan dianalisis dengan analisis korelasi. Nilai negatif (-) pada koefisien korelasi memiliki arti hubungan linear yang berlawanan, sedangkan nilai positif (+) memiliki arti hubungan linear yang searah, serta nol (0) memiliki arti antara karakter satu dengan karakter yang lain tidak terdapat hubungan. Penghitungan nilai koefisien korelasi berdasarkan rumus berikut:

$$
r=\frac{\sum x y-\left(\sum x\right)\left(\sum y\right)}{\sqrt{\left(n \sum x^{2}-\left(\sum x^{2}\right)\left(n \sum y^{2}-\left(\sum y^{2}\right)\right.\right.}}
$$

Keterangan: 
$\mathrm{r}=$ koefisien korelasi; $\mathrm{x}, \mathrm{y}=$ karakter yang diukur keeratannya

(Mattjik, 2006)

\section{HASIL DAN PEMBAHASAN}

Nilai koefisien korelasi antar karakter pertumbuhan dan hasil tanaman kacang panjang diperlihatkan pada Tabel 1. Karakter pertumbuhan yang berkorelasi nyata hanya diperlihatkan pada karakter lebar daun terhadap karakter diameter polong. Karakter lebar daun berkorelasi positif nyata terhadap karakter diameter polong, hasil ini menunjukkan bahwa semakin lebar ukuran daun maka akan meningkatkan ukuran diameter polong. Menurut Ulva et al. (2019) pertambahan ukuran daun dapat memacu hasil fotosintat yang tinggi yang berdampak terhadap perkembangan optimal tanaman. Karakter panjang daun dan lebar daun berkorelasi positif tidak nyata terhadap karakter panjang polong dan berat per polong menggambarkan bahwa perbedaan panjang daun dan lebar daun tidak diikuti perbedaan panjang polong dan berat per polong kacang panjang. Hakim (2010) melaporkan bahwa tidak terjadi korelasi yang nyata pada karakter panjang polong terhadap hasil biji per tanaman.

Tabel 1. Korelasi antar karakter pertumbuhan dan hasil tanaman terung

\begin{tabular}{lcccccccc}
\hline Karakter & PD & LD & UP & PP & DP & BPP & JPPT & BPPT \\
\hline PD & 1 & 0,355 & 0,104 & 0,287 & 0,247 & 0,251 & $-0,182$ & $-0,112$ \\
LD & & 1 & $-0,059$ & 0,145 & $0,402^{*}$ & 0,185 & 0,072 & 0,117 \\
UP & & & 1 & $-0,324$ & 0,048 & $-0,368^{*}$ & 0,291 & $-0,345$ \\
PP & & & & 1 & 0,128 & $0,948^{* *}$ & $-0,306$ & $0,404^{*}$ \\
DP & & & & 1 & 0,261 & 0,054 & $-0,139$ \\
BPP & & & & & 1 & $-0,231$ & $0,417^{*}$ \\
JPPT & BPPT
\end{tabular}

Karakter umur panen berkorelasi positif tidak nyata terhadap karakter diameter polong dan jumlah polong per tanaman. Hasil tersebut memperlihatkan bahwa umur panen yang lama tidak memberikan kontribusi terhadap pertambahan diameter polong dan jumlah polong per tanaman. Hasil ini hampir sama dengan penelitian Hapsari (2014) bahwa karakter umur bunga dan umur panen pada tanaman kacang hijau berkorelasi positif tidak nyata terhadap jumlah biji per polong. Selanjutnya karakter umur panen berkorelasi negatif nyata terhadap karakter berat per polong serta berkorelasi negatif tidak nyata terhadap karakter panjang polong dan berat polong per tanaman. Hasil tersebut menunjukkan bahwa semakin cepat umur panen kacang panjang belum tentu menghasilkan panjang polong dan berat per polong yang optimal begitupun sebaliknya.
Karakter panjang polong, diameter polong, berat per polong, jumlah polong per tanaman dan berat polong pertanaman merupakan karakter yang sangat berkontribusi terhadap hasil tanaman kacang panjang. Berdasarkan hasil penelitian karakter panjang polong berkorelasi positif sangat nyata terhadap karakter berat per polong dan berkorelasi positif nyata terhadap karakter berat polong per tanaman serta berkorelasi negatif tidak nyata terhadap karakter jumlah polong per tanaman. Hasil tersebut menunjukkan bahwa semakin panjang polong maka semakin berat polong dan semakin besar juga berat polong per tanaman yang dihasilkan. Perbedaan karakter panjang polong genotipe kacang panjang yang diuji tidak menunjukkan perbedaan yang nyata pada karakter jumlah polong per tanaman.

Karakter diameter polong berkorelasi positif tidak nyata terhadap karakter berat per polong 
dan jumlah polong per tanaman serta berkorelasi negatif tidak nyata terhadap karakter berat polong per tanaman. Hasil tersebut menandakan bahwa ukuran diameter polong yang besar tidak berpengaruh terhadap pertambahan berat per polong dan jumlah polong per tanaman, begitu juga sebaliknya ukuran diameter polong yang kecil tidak berpengaruh terhadap berkurangnya berat polong per tanaman. Karakter berat per polong berkorelasi positif nyata terhadap karakter berat polong per tanaman dan berkorelasi negatif tidak nyata terhadap karakter jumlah polong per tanaman. Hasil tersebut menunjukkan semakin besar berat polong kacang panjang maka semakin besar berat polong per tanaman yang dihasilkan, namun semakin kecil berat per polong yang dihasilkan tidak berpengaruh terhadap sedikitnya jumlah polong yang dihasilkan. Karakter jumlah polong per tanaman berkorelasi positif sangat nyata terhadap karakter berat polong per tanaman yang berarti semakin banyak jumlah polong maka semakin besar berat per polong yang dihasilkan. Hasil ini sejalan dengan penelitian bahwa komponen hasil jumlah tandan buah per pohon berpengaruh terhadap jumlah buah dan bobot buah jarak (Wardiana dan Pranowo, 2010)

\section{KESIMPULAN}

Berdasarkan hasil analisis korelasi yang telah dilakukan pada penelitian ini disimpulkan bahwa karakter lebar daun berkorelasi positif nyata terhadap karakter diameter polong. Karakter panjang polong, berat per polong dan jumlah polong per tanaman berkorelasi positif nyata terhadap karakter hasil berat polong per tanaman. Karakter panjang polong, berat per polong dan jumlah polong per tanaman dapat digunakan sebagai pedoman kriteria seleksi tanaman kacang panjang.

\section{UCAPAN TERIMA KASIH}

Ucapan terima kasih disampaikan kepada Kementerian Riset dan Teknologi yang telah memberikan dana untuk pelaksanaan penelitian melalui program pendanaan dan pembiayaan Penelitian Dosen Pemula (PDP) dengan nomor kontrak:182/SPH/LT/DRPM/2020;078/SP2H/LT /DRPM/2020;099/SP2H/PPM/DRPM/2020; 1703/SP2H/AMD/MULTI/LL2/2020.

\section{DAFTAR PUSTAKA}

[BPPP] Balai Penelitian dan Pengembangan Pertanian. 2011. Petunjuk Teknis Budidaya Kacang Panjang. Diambil dari http://repo.mercubuanayogya.ac.id/hortikultu ralitbangpertanian/leaflet/JuknisKacangPanja ng.pdf.

Elba, D.S., Sa'diyah, Nurmiaty, Y. (2015) Korelasi antara karakter buah terung (Solanum melongena L.) dan pengujian viabilitas beneih setelah disimpan 6 bulan, $J$. Agrotek Tropika, 3(2), 181-184.

Fatimah, S., Ariffin, Rahmi, A.N., Kuswanto. (2020) Keragaman genetik galur harapan kacang bambara (Vigna subterranea (L.) Verdc.), lines. Agrovigor, 13(2), 141-148.

Gangapur, D.R., Prakash, B.G., Salimath, P.M., Ravikumar, R.L., Rao, M.S.L. (2009) Correlation and path analysis in Indian mustard (Brassica juncea L. Czern and Coss), Karnataka J. Agri Sci, 22(5), 971977.

Hapsari, R.T., (2014) Pendugaan keragaman genetik dan korelasi antara komponen hasil kacang hijau berumur genjah, Buletin Plasma Nutfah, 2(2), 51-58.

Hendriyani, I.S., Setiari, N. (2007) Kandungan klorofil dan pertumbuhan kacang panjang (Vigna sinensis) pada tingkat penyediaan air yang berbeda, J. Sains \& Mat, 17(3), 145150.

Lantoi, R.R., Darman, S., Patadungan, Y.S. (2016) Identifikasi kualitas tanah sawah pada beberapa lokasi di Lembah Palu dengan metode skoring lowery, J. Agroland, 23(3), 243-250.

Lelang, M.A. (2017) Uji korelasi dan analisis lintas terhadap karakter komponen pertumbuhan dan karakter hasil tanaman tomat (Lycopersicum esculentum, Mill), Jurnal Pertanian Konservasi Lahan Kering, 2(2), 33-35.

Mattjik, A.A., Sumertajaya, I.M. (2006) Perancangan Percobaan dengan Aplikasi SAS dan MINITAB. ID: Bogor.

Narendri, G.O., Yulianah, I., Kuswanto. (2017) Pemurnian genetik empat varietas kacang panjang (Vigna sesquipedalis (L.) Fruwirth) berpolong ungu, Plantropica, 2(1,: 1-9.

Reswari, H.A., Syukur, M., Suwarno, W.B. (2019) Kandungan antosianin dan karotenoid 
serta komponen produksi pada berbagai genotipe kacang panjang berpolong ungu dan hijau, J. Agron. Indonesia,. 47(1), 61-67.

Sa'diyah, N., Widiastuti, M., Ardian. 2013. Keragaan, keragaman dan heritabilitas karakter agronomi kacang panjang (Vigna unguiculata) generasi F1 hasil persilangan tiga genotipa, J. Agrotek. Tropika, 1(1), 3237.

Subaedah, S.T., Numba, S., Saida. (2018) Penampilan pertumbuhan dan hasil beberapa genotipe jagung calon hibrida umur genjah di lahan kering, J. Agron. Indonesia, 46(2), 169-174.
Ulva, D.A., Supriyono, Pardono. (2019) Efektivitas pupuk daun terhadap pertumbuhan dan hasil kedelai pada sistem tanpa olah tanah, Agrosains. 21(2), 29-33.

Wardiana, E., Pranowo, D. (2010) Pendugaan parameter genetik, korelasi dan klasterisasi dua puluh genotip jarak pagar (Jatropa curcas L.) di kebun percobaan Pakuwon, Zuriat, 21(1), 1-14. 